\title{
MALENE MOLDING
}

\section{TILBAGE TIL GADEN}

\section{Børn og unges liv på gaden i Nairobi}

Elisabeth var en kendt person. Gadefolk, unge og gamle, mænd og kvinder fyldte de mange bænke op, der var stillet frem i gården, hvor hendes begravelse skulle finde sted. Hendes familie, socialarbejdere og en præst var kommet samt ledere fra de forskellige gadebørnsprojekter, hun havde været involveret i i løbet af de seks år, hun havde levet på gaden.

Jeg havde mødt Elisabeth i en ungdoms- og børnedetention ${ }^{1}$ nogle måneder forinden. Lederen på det gadebørnsprojekt, som jeg var tilknyttet, havde bedt socialarbejderen Agnes og mig om at finde Elisabeth, som var blevet arresteret, og som på daværende tidspunkt var for syg til at overleve et ophold i en ungdoms- og børnedetention. Elisabeth havde aids. Ideen med at finde hende var at bringe hende med til projektcenteret for der at tilbyde hende ordentlig sygepleje og muligheden for at $d \varnothing$ inden for fredelige og relativt trygge rammer. På centeret ville hun være blandt folk, som havde kendt hende i lang tid, og som hun derfor havde opbygget en relation til. Sammenlignet med en børne- og ungdomsdetention kunne projektcenteret således tilbyde hende et mere humant miljø at tilbringe sin sidste tid $\mathrm{i}$.

Vi fandt Elisabeth og fik hende bragt tilbage til projektcenteret, hvor hun med det samme påbegyndte en medicinsk behandling. Derudover fik hun logi, pleje, tøj, mad og opmærksomhed. Alligevel gik hun, hver gang lejligheden bød sig, på sine urimeligt tynde ben væk fra centeret og hele vejen ind til Nairobis bycentrum, til den gruppe af gadefolk, som hun på daværende tidspunkt tilhørte. Der ville vi finde hende på toppen af en skraldebunke, sniffende lim og lykkeligt smilende eller i dybe smerter på fortovet med en plastikkop foran sig, tiggende. Til trods for adskillige gadebørnsprojekters mangeårige indsats for at få Elisabeth væk fra gaden syntes hun at foretrække livet på gaden. Derfor blev hun af en socialarbejder bragt fra gaden direkte til et offentligt hospital, hvor hun døde alene i en alder af 15 år.

Denne artikel handler om folk, der lever og arbejder på gaden i Nairobi, Kenya. Den er skrevet på baggrund af et feltarbejde, som jeg udførte fra september 1995 til maj 1996, hvor jeg var tilknyttet et rehabiliteringscenter for gadepiger. Artiklen sigter på at identificere det som kaldes ,pull-faktorerne“, det vil sige, hvad det er, livet på gaden kan tilbyde folk, således at denne livsstil kommer til at fremstå som tiltrækkende i forhold til andre mulige livsstile. Fokus adskiller sig dermed fra studier af politiske, økonomiske og 
sociokulturelle faktorer, også kaldet ,push-faktorer“, der bevirker, at folk forlader deres hjem og starter et liv på gaden.

Inspireret af sociologen Pierre Bourdieu anskuer jeg i artiklen gadelivet som en livsstil, der udspiller sig inden for et socialt felt karakteriseret ved specifikke spilleregler og konkurrerende sociale positioner af symbolsk kapital. Ved at introducere begrebet gadelivsekspertise samt dets tilknytning til motivation og identifikation argumenterer jeg for, at livet på gaden fremstår som attraktivt for folk, der har opbygget kompetence inden for dette felt. Jeg viser, hvordan disse folk i kraft af deres kompetence besidder nogle positioner i feltet, der både er relateret til magt, prestige og succes, hvilket motiverer dem til at fortsætte denne livsstil, som de med tiden er kommet til at identificere sig positivt med.

\section{Et paradoks}

Kort efter at jeg påbegyndte mit feltarbejde, blev jeg opmærksom på en adfærdsform blandt pigerne på rehabiliteringscenteret, der forekom både overraskende og uforklarlig. Tilsyneladende socialt velfungerende piger ville ligesom Elisabeth pludselig stikke af fra centeret for at vende tilbage til gaden. Dette forekom paradoksalt, fordi disse piger havde adgang til kost og logi, havde vennner, mulighed for at gå i skole og levede i relativ tryghed sammenlignet med livet på gaden. Der samlede de mad fra skraldebunker, sov i sække på gaden, blev regelmæssigt arresteret af politiet, slået, voldtaget og på andre måder udsat for, hvad der forekommer som ubehagelige overgreb. Deres tilsyneladende præference for gadelivet skabte en undren over, hvordan det kunne være et attraktivt alternativ til andre livsstile? Med andre ord, hvorfor vendte piger som Elisabeth tilbage til gaden?

For at opbygge en bredere forståelse for pigernes valg af livsstil valgte jeg i min undersøgelse og i modsætning til mange andre studier af gadebørn ${ }^{2}$ at inddrage de unge, voksne og ældre gadefolk, som børn på gaden i Nairobi lever blandt og dagligt interagerer med. Dette er en af årssagerne til, at jeg anvender den mere generelle term ,gadefolk“ i stedet for gadebørn. En anden begrundelse for min præference for termen gadefolk er de værdiladede diskurser, der omgiver termen gadebørn i Kenya både blandt ,non-governmental organisations“ (ngo'er), kirkeorganisationer, repræsentanter fra FNs organisationer samt andre institutioner, som beskræftiger sig med gadebørn, og på et mere generelt plan, som antropologen Benno Glauser (1990) påpeger i en artikel, hvor han dekonstruerer begrebet. Blandt institutioner i Kenya, som arbejder med gadebørn, synes der at herske en enighed om, at gadens børn og unge er uskyldige ofre for etniske uroligheder, fattigdom, opløsning af socialt og $ø$ konomisk belastede familier og andre uheldige omstændigheder, som derfor øjeblikkeligt bør hjælpes af sagkyndige ${ }^{3}$ (ANCCPAN 1995: $41)^{4}$. På et mere generelt plan opfattes gadebørn og deres ofte kriminelle og aggressive adfærd og livsstil som truende og afvigende fra konventionelle ideer om, hvilke omstændigheder der er hensigtsmæssige for børn at vokse op i (Glauser 1990:46). Med andre ord anses gadelivet ikke blot som et forkert og ubetinget dårligt liv vis-a-vis konventionelle ideer om barndom. Gadebørn fratages også deres handlekraft og kompetencer som individer, fordi deres liv og tilstedeværelse på gaden hovedsageligt forklares gennem diskurser som de ovennævnte. Jeg ønsker i stedet at etablere et syn på gadebørn som kompetente strategerende aktører og yderligere at betragte livet på gaden som en livsstil, der ligesom andre livsstile rummer både positive og negative aspekter. 
Inspireret af den nye amerikanske kognitive antropologi (D'Andrade \& Strauss 1992) anvender jeg begrebet ,gadelivsekspertise“ til at opløse det opstillede paradoks. Inden for den kognitive antropologi anskues ekspertise som en slags kulturel kompetence, der ikke er knyttet til alder og fysiologisk udvikling, men til personlige dispositioner og udvikling af motivation og identitet ${ }^{5}$ i forhold til en social verden. Ekspertisebegrebet, som det anvendes inden for den kognitive antropologi, bruges således til at påpege og forklare kulturel diversitet forstået som den enkelte aktørs motivation og kompetence i forhold til en social verden. Dermed kan begreberne ekspertise og motivation også bruges til at diskutere, i hvilken grad det kulturelle er delt og determinerer adfærd.

I forhold til gadelivet anskuer jeg ekspertise som overlevelsesevner (det vil sige, at jeg fastholder anvendelsen af ekspertise som en kompetence), idet ekspertise refererer til en persons evne til på strategisk vis at indgå i sociale praksiser og positioner ${ }^{6}$ på gaden, der sikrer ham eller hende en fordelagtig fysisk, social og $\varnothing$ konomisk overlevelse. Gadelivsekspertise er således med til at forme den enkelte persons trivsel. Med eksempler fra Nairobi argumenterer jeg for, at gadefolk, der har udviklet en høj grad af ekspertise, ofte indtager sociale positioner på gaden, hvor de oplever både succes og anerkendelse vis-avis andre aktører i feltet. Og yderligere at de på grund af deres succes, position og kompetence gradvist opbygger et positivt selvbillede, som motiverer dem til fortsat at investere i denne livsstil.

Gadelivsekspertise er som begreb operationaliserbart, fordi det kan anvendes til at forstå den diversitet, der karakteriserer gadefolks kompetencer og motivation i forhold til gadelivet og dermed også deres sociale position inden for dette felt. I forlængelse heraf ligger mit ønske om at påpege det uhensigtsmæssige i at betragte og behandle gadebørn som en samlet social kategori, netop fordi gadebørn er forskellige, hvad angår kompetencer og motivation i forhold til gadelivet. Endelig kan ekspertisebegrebet i kraft af dets relation til motivation bruges til at forklare, hvordan gaden kan komme til at fremstå som et attraktivt alternativ til andre livsstile. I det følgende vil jeg kort beskrive den kontekst, som gadefolk i Nairobi lever i.

\section{Gadeliv}

Omtrent 40.000 børn antages at være på gaden i Kenya i dag, hvoraf omkring 25.000 er i Nairobi (Human Rights Watch 1997:15). Dette tal inkluderer ikke de unge, voksne og ældre, der også er på gaden, og som de børn, jeg beskæftigede mig med via min tilknytning til rehabiliteringscenteret, levede blandt. De unge, voksne og ældre udgør de sociale omgivelser for børn på gaden, og det er i denne sociale sammenhæng, at rammerne sættes for børns og unges kunnen og ageren.

Selvom gadefolk generelt synes at færdes over det meste af Nairobi, har de ikke desto mindre et bestemt gruppetilhørsforhold. Hver gruppes tilholdssted kaldes af gadefolk for en choum. Ordet choum er swahilislang og betyder et hjem i en smal gade eller på bagsiden af en bygning. Hver choum er opkaldt efter dens stifter eller tilholdsstedet, typisk en nærliggende bygning. Blandt gadefolk refererer en choum imidlertid ikke blot til tilholdsstedet eller stifteren, men til gruppen af mennesker, som lever der. Når en person bliver medlem af „X“ choum, bliver hun derfor også medlem af „X“ gruppe. Gruppernes størrelser kan variere fra så få som 3 til så mange som 50 mennesker. Der er mange 
choums i Nairobi. I nogle er der kun voksne mænd og kvinder, andre består af blandede aldersgrupper, hvor børn, unge og ældre lever sammen.

Første gang man besøger en choum, lægger man, dels på grund af en intens stank af forrådnelse, dels grundet størrelsen, overvejende mærke til den skraldebunke, som de fleste choums er beliggende ved, og som gadefolkene tilbringer adskillige timer omkring hver dag. Efter nogle besøg bliver det imidlertid klart, at stedet er inddelt i funktionelle sektioner på samme måde som mange andre hjem. Ildstedet, der er bygget op om tre sten, fungerer som køkken, hvor gamle dåser bliver brugt som gryder. Revnerne i de nærliggende mure fungerer som hylder, hvor notesbøger, hospitalsmedlemskort og fotos er gemt. Gamle plastikkander, der ved første øjekast ligner affald, indeholder lim, som sælges og sniffes i choumen. Vasketøj er hængt langs væggene, og gamle papstykker er spredt ud over jorden, hvor medlemmerne normalt sidder. På faste tidspunkter bliver affald dumpet i skraldebunken af de omkringliggende hoteller og forretninger, og umiddelbart derefter sorterer gadefolkene papir, plastik, metal og fødevarer til henholdsvis genbrug, salg og madlavning.

Choumen er et møde- og gemmested. Hvis en ung mand har stjålet noget $\mathrm{i}$ byen, og folk forfølger ham, løber han typisk hen til choumen for at gemme sig og om nødvendigt for at få assistance fra de andre gadefolk. Ligeledes hvis en person er syg, assisterer medlemmerne, så vidt det er muligt. Sammenlignet med de travle hovedgader kommer politiet og andre borgere kun sjældent i choumen, hvor en sær følelse af privathed derfor eksisterer. I choumen hviler folk sig, de spiller kort og slapper af. En choum er et tilholdssted, og for nogle gadefolk et hjem i byen. Et slående træk ved choumen er, at medlemmerne altid er bekendt med hinandens aktiviteter. Hvis man søger efter en bestemt person, tager man blot hen til hendes eller hans choum for at blive informeret om, hvor i verden personen befinder sig. En choum er et slags informationscenter og et knudepunkt i gadefolks sociale netværk.

\section{Et felt}

Gadefolk lever i en slags symbiotisk relation med Nairobi og dens øvrige beboere. Gadefolks opholdssted er byens gader, og deres basale overlevelse er sikret gennem Nairobis befolknings daglige produktion af tonsvis af affald, som gadefolkene sorterer, videresælger og konsumerer. Derudover tilbyder gadefolk forskellige ydelser som for eksempel prostitution eller billig manuel arbejdskraft til de folk, der bebor eller passerer gennem byen. Endelig udnytter gadefolk byens menneskemylder og almene kaotiske tilstand til at tilvejebringe forskellige ressourcer såsom mad, tøj, penge, vand eller forbipasserendes personlige ejendele, ofte gennem tyveri. De stjålne goder videresælges til byens forskellige hælere, som igen sælger det til byens dårligt bemidlede beboere til priser, der ligger under markedsprisen. Trods denne daglige interaktion mellem gadefolkene og Nairobis $\emptyset$ vrige beboere udspiller livet $\mathrm{i}$ choumen sig ikke desto mindre i en unik social verden, der er kendetegnet ved en række specifikke konkurrerende sociale positioner og praksiser.

Jeg har ladet mig inspirere af Bourdieus begreb ,felt" til at indfange og beskrive denne sociale verden på godt og ondt. Bourdieu karakteriserer et felt som et netværk af objektive historiske relationer mellem positioner, der er defineret ved deres relationer til andre positioner og deres forankring i bestemte former for magt (,symbolsk kapital“) 
(Bourdieu \& Wacquant 1992:16, 97). Symbolsk kapital er en ressource, der er forbundet med ære og prestige (op.cit.:229-31) og som efterstræbes inden for et socialt felt. Det er en ressource, der er socialt anerkendt, og som folk inden for feltet investerer og benytter som et redskab til at fastholde eller forbedre deres sociale position. Et felts symbolske kapital er centralt at identificere både for at forstå de forskellige og konkurrende positioners eksistens og for at identificere et felts grænser. Et felts grænser er nemlig lokaliseret der, hvor den symbolske kapital ikke anerkendes eller anvendes (op.cit.:98, 100). Symbolsk kapital kan for eksempel være organisatorisk talent, viden om fremmedsprog eller evnen til at kontrollere adgangen til forskellige objekter eller positioner (Hervik 1996:4).

Den symbolske kapital, som værdsættes, efterstræbes og investeres i choumen som felt, er gadelivsekspertise. Som allerede nævnt, er ekspertise den enkelte gadepersons evne til at indgå i sociale praksiser og positioner i choumen på måder, som sikrer ham eller hende en fysisk, social og $\varnothing$ konomisk overlevelse og anseelse. Gadelivsekspertise og gadeerfaring er således to forskellige ting. Ekspertise forudsætter gadeerfaring, men rummer samtidig mere end erfaringen, nemlig evnen til at anvende og udnytte den på en strategisk og hensigtsmæssig måde, der sikrer den enkelte person en daglig overlevelse og en fordelagtig position i choumen. Man kan derfor godt have erfaring fra gaden uden at have gadelivsekspertise. Ekspertise er noget, folk kan udvikle, efterhånden som de etablerer en form for intuitiv fornemmelse for feltet eller med Bourdieus ord ,a feel for the game“ (Bourdieu 1990:39-40; Bourdieu \& Wacquant 1992:98), det vil sige for de konkurrerende positioner og sociale spilleregler, der former den daglige interaktion. Folk med en intuitiv fornemmelse for feltet er i stand til på strategisk, men også socialt accepteret vis at begå sig og derved fastholde eller forbedre deres position.

De sociale positioner i choumen har både et subjektivt og objektivt aspekt, og gadefolks sociale omdømme og daglige trivsel relaterer sig til begge aspekter, men især til det subjektive aspekt. Det objektive aspekt knytter sig til positioner, som flere personer kan indtage. I choumen vil dette typisk være den prostituerede, tiggeren, tyven, personen, der samler skrald og sælger det, forhandleren af lim og andre rusmidler, choumlederen og daglejeren. Det subjektive aspekt relaterer sig til den måde, hvorpå den enkelte person forvalter sin position, hvilket afhænger af hans eller hendes personlighed og gadelivsekspertise. Kiboi, for eksempel, er en 25-årig gademand med meget gadelivsekspertise. Han har udviklet en unik sans for choumen, det vil sige for de konkurrerende positioner og sociale spilleregler, som karakteriserer den. Og samtidig formår han at forvalte sin ekspertise således, at han i dag ikke blot indtager en ekstremt fordelagtig position i choumen; han har også formået at investere $\mathrm{i}$ andre felter, hvor han ligeledes ser ud til at klare sig godt. Faktisk er Kiboi i dag så velstillet, at han i princippet kunne lægge gadelivet bag sig. For nogle år siden var Kiboi en stor tyv, og i den forbindelse tilvejebragte han en masse penge. For disse penge købte han ejendomme i et af Nairobis slumkvarterer, hvor han i dag lejer huse ud. Alligevel tilbringer han langt den største del af sin tid i choumen, hvor han er leder. Han monopoliserer alt salg af lim, marihuana og andre rusmidler og opkøber skrald af gadefolk og videresælger det til firmaer, som bearbejder det til genbrug. I modsætning til disse firmaer, som kun opkøber skrald i store mængder, så betaler Kiboi gerne gadefolk, der samler skrald, for mindre mængder. Dette er en fordel for dem, der løbende har brug for kontanter. Kiboi har således identificeret en måde, hvorpå han kan gøre sin forretning særlig attraktiv for gadefolk, og hvor han dermed kan konkurrere med de større firmaer, der også opkøber skrald. Kiboi er, hvad jeg vil kalde, en gade- 
ekspert. Gadeeksperter er defineret ud fra deres opbyggede kompetence i relation til choumen som felt, hvor de besidder en stor mængde symbolsk kapital, som de ofte er motiverede til at reinvestere i feltet, netop fordi de derved kan fastholde eller forbedre deres succesfulde sociale position.

I choumen kan den enkelte aktørs status og kompetence anskueliggøres ved et kontinuum, hvor novicen, der endnu ikke kender til gadelivet, og som ikke har udviklet nogen betydelig viden eller færdigheder i forhold til denne livsstil, befinder sig i den ene ende og eksperten i den anden. Der er altså tale om et udviklingsforløb, hvor grader af gadelivsekspertise adskiller novicen fra eksperten ${ }^{7}$. Det betyder imidlertid ikke, at alle gadefolk med tiden ender som eksperter, tværtimod er folk mere eller mindre eksperter og novicer. Feltet er nemlig karakteriseret ved bevægelse og foranderlighed, idet gadefolk bevæger sig ind og ud af det. De bliver arresteret, opholder sig på projekter som for eksempel det rehabiliteringscenter, jeg var tilknyttet, nogle kommer til penge og flytter midlertidigt ind på byens billige pensioner eller ud i slummen og så fremdeles. Folk kommer og går og opbygger derfor forskellige grader af ekspertise og motivation i forhold til feltet, hvor deres positioner ligeledes forandrer sig.

Det er imidlertid en pointe, at alle de folk, som starter et liv på gaden, inden for en relativ kort periode både opbygger en vis mængde ekspertise og et billede af sig selv som aktører i choumen, det vil sige som gademennesker. Dette skyldes dels, at de, som ikke udvikler ekspertise, simpelthen ikke kan overleve på gaden, og dels at gadelivet som livsstil er benhårdt og derfor hurtigt indskriver sig i folks bevidsthed. ${ }^{8}$ Det er i denne forbindelse vigtigt at nævne, at folk, når de starter et liv på gaden, ikke gør det af lyst, men fordi de oplever, at der ikke er andre alternative løsninger på de problemer, som har drevet dem på gaden; ligesom novicers opbyggelse af kompetence vis-a-vis choumen som felt ikke er motiveret af lyst eller frivillighed, som det kan være for gadeeksperter eller aktører i andre felter som for eksempel inden for sport, romantik eller den akademiske verden. Med andre ord er choumen karakteriseret ved en diversitet, der relaterer sig til gadefolkenes forskellige mængder af ekspertise og motivation til at fastholde eller forbedre deres position. Hvordan folk i det daglige forvalter deres positioner inden for rammerne af de sociale spilleregler, der regulerer interaktionerne i choumen, vil de følgende eksempler fra gaden vise.

\section{Sociale spilleregler}

I choumen eksisterer en ,,code of conduct“, det vil sige en række sociale normer eller i en bourdieusk terminologi spilleregler, som regulerer den sociale interaktion blandt gadefolk. Spillereglerne kommer til udtryk ved at folk viser konformitet i forhold til bestemte adfærdsmønstre som for eksempel at sniffe lim, ryge cigaretter, at klæde sig i gammelt tøj og at opføre sig i overensstemmelse med de eksisterende alders- og kønshierarkier. ${ }^{9}$

Det er muligt at identificere flere årsager til, hvorfor konformitet er af så stor betydning i choumen. I Kenya er gadefolks tilstedeværelse på gaden samt de fleste af de indkomstgenererende aktiviteter, de ernærer sig gennem, ulovlige. Som en konsekvens heraf betragtes folk, der undgår at deltage i ulovlige aktiviteter, som trusler mod choumen. Gadefolk anskuer ganske enkelt sådanne personer som potentielle stikkere, der kan angive gadefolkene og deres ulovlige aktiviteter til politiet. Angivelse kan føre til, at chou- 
men bliver ødelagt og gadefolk arresteret. Choumens eksistens er derfor afhængig af, at samtlige medlemmer bakker op om de aktiviteter, der dagligt finder sted, og handler i solidaritet med de andre medlemmer. At opføre sig i overensstemmelse med de sociale spilleregler er en måde at signalere en velvilje over for de andre gadeflok og en accept af deres livsstil velvidende, at dette indbefatter en deltagelse i aktiviteter, som er ulovlige såsom at sniffe lim og tage stoffer. Derudover kommer gadefolkene fra forskellige egne i og omkring Nairobi, og mange kender derfor ikke de andre medlemmer i choumen eller føler nogen form for samhørighed med dem ved deres ankomst på gaden. Et fællesskab og en samhørighed bliver imidlertid etableret ved, at nye medlemmer tvinges til at deltage i ulovlige aktiviteter, hvorved de selv bliver afhængige af de andre medlemmers loyalitet og støtte. Det sociale krav om at vise konformitet er således med til at etablere og fastholde det sociale fællesskab, som choumen udgør.

En anden spilleregel knytter sig til alder. Ligesom i det kenyanske samfund generelt eksisterer der i choumen et aldershierarki. Når gadefolk bliver ældre, tilskrives de automatisk respekt, ansvar og autoritet. Deres stemme bliver i stigende grad hørt, og de får stadig flere sociale rettigheder. ${ }^{10}$ De yngre medlemmer i choumen forventes at vise de ældre respekt, typisk ved at adlyde dem og ved at lytte til deres råd, hvilket ofte indebærer, at de bliver groft udnyttet. For eksempel bliver yngre drenge ofte sendt ud på ærinder såsom at hente vand og købe cigaretter, eller de bliver bedt om at stjæle noget $\mathrm{i}$ byen og vende tilbage med de stjålne varer, som de ældre medlemmer derefter tager og videresælger. Som regel får de yngre medlemmer kun en minimal del af fortjenesten, selvom det reelt er dem, der har skaffet de varer, som bliver solgt. De yngre kvindelige medlemmer bliver også sendt på ærinder. De bliver bedt om at tigge og til tider bliver de voldtaget eller solgt som børneprostituerede.

Relationen mellem de ældre og yngre medlemmer i choumen er kompliceret og anspændt. På den ene side er de yngre medlemmer afhængige af de ældres beskyttelse og knowhow, ${ }^{11}$ på den anden side giver de ofte udtryk for, at de bliver groft udnyttet. I hvor høj grad folk indordner sig de sociale spilleregler, afhænger imidlertid af, hvor meget gadelivsekspertise de har udviklet.

\section{Trivsel på gaden og gadelivsekspertise}

Mercy er en 13-årig gadepige, der lige er vendt tilbage til gaden efter et længere ophold hos sin familie på landet, da jeg møder hende for første gang. Inden Mercy tog hjem, havde hun været på gaden i omkring to år. Efter at hun er vendt tilbage til Nairobi, er hun blevet konfronteret med de problemer, som yngre og nyankomne piger og kvinder typisk støder på. Hun fortæller, at hun ofte bliver voldtaget af gademænd og appellerer til socialarbejderen Agnes og mig om hjælp med at finde et alternativ til gadelivet. Mercy fortæller, at hun ikke er på gaden, fordi hun har lyst til at være der, men fordi hun har det elendigt. Hun virker ulykkelig og udmattet, og hun trives tydeligvis ikke. Hun hævder at være tigger, men hendes smarte tøj peger på, at hun også har andre indtægtskilder. Gadefolkene fortæller mig, at hun er prostitueret.

Når jeg møder hende på gaden, er hun for det meste sammen med en gruppe piger på sin egen alder, der som hun selv indtager mindre fordelagtige positioner i choumen. Ifølge Mercy er livet på gaden meget lettere for ældre gadefolk: „,De bliver ikke voldtaget og 
banket. De små er hjælpeløse. Hvis du forsøger at stikke af, slår de dig“. Når jeg spørger Mercy, hvilken gruppe hun anser sig for at tilhøre, svarer hun omgående: „Jeg er lille“.

Den distinktion, som Mercy angiver at eksistere mellem de ældre og yngre gadefolk samt de dertil relaterede problemer, reflekterer hendes egen position som en ung person, der er underlagt ældre gadefolks udnyttelse, kontrol og mangel på respekt. Til trods for at Mercy har været på gaden i et par år, inden hun tog hjem, og derfor har noget erfaring, så har hun ikke været i stand til at etablere et socialt netværk, der kan beskytte hende mod for eksempel at blive voldtaget og slået. Med andre ord, Mercy formår ikke at etablere fordelagtige sociale alliancer, som hun kan trække på for at forbedre sin underordnede position i choumen og dermed sin hverdag. Hendes klager over sin tilværelse på gaden reflekterer derfor også, at hun ikke har udviklet særlig meget ekspertise, selvom hun har erfaring fra gaden. Forskellen mellem ældre og yngre gadefolk er uklar i den forstand, at yngre gadefolk, der har udviklet ekspertise godt kan associere sig selv med ældre gadefolk og derved nyde godt af den respekt og sociale magt, som ældre personer i choumen er tilskrevet. Som jeg i det følgende vil illustrere, kan folk med et højt niveau af gadelivsekspertise manipulere med de sociale spilleregler, der ellers regulerer den sociale interaktion i choumen.

Lucy er kun et år ældre end Mercy, men hun omgås hovedsagelig de lidt ældre kvinder, der er indflydelsesrige i choumen, som bliver respekteret og har en del ekspertise sammenlignet med Mercy og hendes venner. Når jeg støder ind i Lucy, virker hun relativt velfungerende og glad, og hun ser ud til at trives. Lucys relation til de ældre kvinder placerer hende $\mathrm{i}$ en fordelagtig situation. For det første fordi hun derved bliver associeret med de ældre gadefolk og derfor kan kontrollere yngre medlemmer. For det andet fordi de ældre og erfarne kvinder har et socialt netværk, hun kan trække på i dagligdagen og derved undgå for eksempel at blive voldtaget, slået eller sendt på ærinder. Endelig er Lucy prostitueret. Hun er imidlertid ikke underlagt de ældre kvinder, der ofte arbejder som mellemmænd ${ }^{12} \mathrm{i}$ forholdet mellem de yngre piger og klienterne, og som nyder godt af denne position, fordi de bliver betalt af klienterne for at etablere kontakten. Tværtimod er det mit indtryk, at hun selv forhandler med klienterne og måske indtager positionen som mellemmand. Lucy formår at udnytte sine sociale evner til at etablere et beskyttende netværk blandt de ældre gadekvinder, som hun også associerer sig med i hverdagen trods sin relativt unge alder.

Sammenlignet med Mercy har Lucy tydeligvis mere gadelivsekspertise. Hun handler på måder, der karakteriserer ældre gadekvinder, hvorved hun opfattes som sådan. Yderligere influerer hendes tilknytning til de ældre gadefolk hendes fysiske, sociale og muligvis også økonomiske overlevelse og position på gaden. Som Bourdieu argumenterer, så gennemtrænger den symbolske kapital i et felt de principper, der normalt former interaktionen i feltet (Bourdieu \& Wacquant 1992:101). Dette synes også at være tilfældet i choumen, hvor Lucy i kraft af sin ekspertise er i stand til på socialt accepteret vis at manipulere med spilleregler, nemlig det sociale krav om at vise konformitet i forhold til blandt andet det eksisterende aldershierarki, som ellers regulerer den sociale interaktion. Omvendt er folk med mindre mængder af ekspertise tvunget til at vise konformitet i forhold til de samme regler, hvilket kan indebære, at de ligesom Mercy er underlagt ældre gadefolks kontrol og til tider misbrug.

Sammenligningen af Lucys og Mercys forskellige grader af ekspertise illustrerer, hvordan gadelivsekspertise former den enkelte aktørs måde at håndtere hverdagen på 
inden for det sociale felt, som choumen udgør, og dermed også den enkelte persons position og trivsel på gaden. Lucys og Mercys forskellige positioner på gaden eksemplificerer den diversitet, der karakteriserer feltets aktører. Alligevel kan man med disse eksempler i tankerne forledes til at tro, at Lucys evner til at klare sig bedre end Mercy skyldes, at hun er et år ældre. Dette er imidlertid ikke tilfældet. Som det følgende eksempel med Helen på 11 år illustrerer, så kan gadefolk sagtens være yngre end Mercy og klare sig bedre til trods for, at de rangerer som „smä“ $i$ det sociale aldershierarki $i$ choumen. Ekspertise og alder er, med andre ord, ikke nødvendigvis sammenhængende faktorer. Og at forstå og klassificere gadebørn ud fra deres alder er derfor ikke altid hensigtsmæssigt.

Helen arbejder om natten ligesom de fleste andre gadepiger som prostitueret, hvor hun er underlagt de ældre gadekvinder, der etablerer kontakten mellem hende og klienterne. Som det ofte er tilfældet, bliver de ældre kvinder betalt af klienterne for at skaffe kontakten, og derudover tager de, i det omfang det er muligt, store dele af de penge, som de yngre piger bliver betalt af klienterne. Kvinderne udnytter med andre ord, at de er ældre end Helen, og at de har mere prestige og magtfulde positioner i choumen. Ligesom Lucy har Helen imidlertid udviklet en del ekspertise, dels i forhold til prostitution, men også i forhold til choumlivet. I modsætning til folk, der er nye på gaden, og som kæmper for at blive socialt accepteret i choumen, for at få et socialt netværk og lære at overleve, så kæmper Helen for at forbedre sin i forvejen veletablerede position ved at udvikle modstrategier, der $\mathrm{g} \emptyset \mathrm{r}$ hende i stand til at beholde store dele af de penge, hun tjener. I forhold til sit arbejde som prostitueret har hun på kreativ vis fundet måder at gemme sin indtjening på, der gør hende i stand til at undgå de ældre kvinders udnyttelse, ikke bare af hendes unge alder, men også hendes underordnede position inden for prostitution. Helen fortæller mig:

Det er ikke altid, at pengene bliver taget. Hvis du er klog, beholder du de store summer i de bukser, som du har på inden under kjolen. Du gemmer pengene der, hvor du drejer bukserne rundt, og beholder et mindre beløb i hænderne. Så lader du som om, at det er de eneste penge, du har fået. Ved at gøre sådan, får de store piger kun få penge.

Snarere end at være et passivt offer for de ældre pigers dominans tager Helen initiativ til at ændre sin ufordelagtige position. Hendes refleksioner over sin situation rejser imidlertid spørgsmålet om, hvorfor hun ikke bruger sin ekspertise til at lave alliancer med de ældre kvinder på samme måde som Lucy og dermed undgår at blive behandlet som et yngre medlem? For det første er Helen tre år yngre end Lucy, og hendes barnlige udseende vanskeliggør, at hun kan indtage positionen som mellemmand. For det andet er hun mindre moden end Lucy både fysisk og psykisk, og muligheden for at associere sig med de ældre kvinder som deres ligemænd er derfor ikke realistisk. Folks chancer for at forbedre eller fastholde deres positioner inden for et felt afhænger af deres placering $\mathrm{i}$ det strukturerede rum af positioner (Bourdieu 1994:14). Og der er ingen tvivl om, at Helens placering $\mathrm{i}$ choumen er blandt de yngre medlemmer. Hendes investeringer i choumen og måde at interagere med de andre medlemmer på er således rettet mod andre mål og positioner end for eksempel Lucys og Mercys. Alligevel formår hun, trods sin alder og unge udseende, $i$ kraft af sin ekspertise at håndtere livet $i$ choumen ret godt sammenlignet med mange andre folk på hendes alder.

Ligesom Lucy synes Helen at trives relativt godt på gaden. Når jeg besøger hendes choum, hvor der overvejende er kvinder, fremgår det tydeligt, at Helen bruger de andre 
kvinder, hvis ikke som ,moderagtige“ figurer, da som et beskyttende netværk, hun i stor udstrækning kan regne med. Helens historie eksemplificerer, at gadefolks alder ikke alene siger noget om deres evner til at håndtere livet i choumen eller deres generelle trivsel på gaden. Det gør derimod graden af gadelivsekspertise, som den enkelte person har udviklet. For at forstå gadefolks investeringer i choumen og den måde, hvorpå de forvalter gadelivet, er det nødvendigt at etablere en forståelse både for de grader af ekspertise, som de har udviklet, og deres placering inden for de sociale hierarkier, der regulerer interaktionen i choumen. Det er altså nødvendigt at kende til den sociale kontekst og de sociale positioner, der karakteriserer livet på gaden som felt, og som sætter rammen for folks formåen og trivsel på godt og på ondt.

\section{Ekspertise, motivation og identifikation}

Selvom Lucy associerer sig med de ældre kvinder, og Helen anskues som lille, virker de begge, som om de klarer sig godt og administrerer livet på gaden på en strategisk og hensigtsmæssig måde. Begge formår at udnytte deres ekspertise på en for dem fordelagtig vis, og i modsætning til Mercy appellerer hverken Lucy eller Helen om hjælp til at komme væk fra gaden. Tværtimod har Lucy gennem tiden været tilknyttet diverse gadebørnsprojekter som hun er stukket af fra, hvorpå hun er vendt tilbage til gaden.

På et tidspunkt tog hun tilbage til sit hjem, hvor hun begyndte at gå i skole igen. Hun blev i skolen i to år, men fortæller, at de andre børn blev ved med at stille hende spørgsmål om hendes liv på gaden. $\mathrm{Og}$ da moderen på et tidspunkt anklager Lucy for at have stjålet nogle penge i hjemmet, bliver mistænkeliggørelsen og spørgsmålene, der omgiver hendes tilstedeværelse og person i den hjemmelige sammenhæng, for meget:

I skolen følte jeg mig meget pinligt tilpas. De stillede mig åndssvage spørgsmål såsom: 'Er du gift, og var du ansat som hushjælp'. Jeg blev i skolen i to år. Jeg havde ingen problemer med at være hjemme, men jeg savnede Nairobi, mine venner, lim, marihuana, cigaretter og penge.

Lucy tager derfor tilbage til Nairobi, hvor hun ikke falder udenfor, ikke bliver mistænkeliggjort, men derimod er en succes inden for rammerne af choumen. På gaden er Lucy en ekspert. Med andre ord, hun er, ligesom Kiboi og som Elisabeth var det, en person, der ved, hvordan hun skal begå sig på gaden, og hun er god til det i den forstand, at hun er dygtig til at overleve, passe på sig selv og indgå i prestigefyldte fordelagtige praksiser, positioner og sociale alliancer, som dem hun har knyttet til de ældre gadekvinder.

For Lucy tilbyder gaden en frihed og et liv, der ikke eksisterer i en familiesammenhæng i det rurale område, hun kommer fra. På gaden fører Lucy et selvstændigt liv, hvor hun tjener sine egne penge og har relativ stor selvbestemmelse i forhold til, hvordan hun vil udfylde sin hverdag. Hun kan leve, ryge, drikke, gå i smart tøj og have seksuelle relationer, som det passer hende uden at skulle stå til ansvar over for andre end sig selv. Derudover har hun opbygget et positivt tilhørsforhold til gaden og den livsstil, som gaden tilbyder, hvilket har en motiverende effekt på hende. Dette kommer til udtryk dels i hendes udsagn om, at hun, da hun var hjemme, savnede sine venner på gaden, og om de goder, som gadelivet giver adgang til, og dels ved at hun bliver ved med at vende tilbage til gaden. Hendes positive følelser over for gadelivet knytter også an til en identifikation 
med gadelivet, som jeg observerede blandt andre gadeeksperter. Fælles for sådanne personer var, at hver enkelt havde en klar oplevelse af at være et gademenneske, og yderligere gav udtryk for at have udviklet positive følelser over for dette selvbillede. Med andre ord så syntes gadeeksperterne ikke blot at være ekstremt kompetente $\mathrm{i}$ at forvalte livet på gaden og motiverede af deres succes og prestigefyldte positioner inden for feltet, de syntes også at identificere sig positivt med det. Og det er netop denne cocktail af kompetence, motivation og et positivt selvbillede vis-a-vis gadelivet, der gør, at det kommer til at fremstå som en tiltrækkende livsstil og ikke blot en fortabelse, som folk er henvist til, fordi de er ofre for uheldige omstændigheder som for eksempel fattigdom og mangel på andre alternative livsstile.

Ligeledes forklarer ekspertisens kobling til motivation og identifikation også Elisabeths præference for gadelivet. Ganske vist havde hun opbygget et tilhørsforhold til projektcenteret, fordi hun var kommet der regelmæssigt gennem sin tid på gaden, men det var et tilhørsforhold, der ikke kunne konkurrere med den motivation, kompetence og positive identifikation, som hun gradvist havde opbygget i forhold til gadelivet, og som hun til det sidste var påvirket af som syg og tigger. Historien om Elisabeth eksemplificerer, hvorfor det har værdi at fokusere på pull-faktorerne, det vil sige at opbygge en forståelse for, hvordan gaden, på godt og ondt og over tid, kan komme til at fremstå for folk, der er gadeeksperter. Gadeeksperter er nemlig, i modsætning til novicer, ikke kun på gaden, fordi de er påvirket af nogle push-faktorer, men netop fordi gadelivet for dem fremstår som et attraktivt alternativ til andre mulige livsstile - gadelivet, som det udspiller sig i choumen er nemlig det felt, hvori de udøver deres ekspertise.

\section{Noter}

1. Hvad der svarer til henholdsvis børne- og ungdomsdetentioner og -hjem, administreres i Kenya af Børnedepartementet (Childrens' Departement), som er en offentlig administrativ afdeling. I Kenya er der 11 børne- og ungdomsdetentioner med en samlet kapacitet på i alt 2500 personer (under 16 år). I virkeligheden overskrider antallet af børn og unge, som opholder sig i disse detentioner, langt den angivne kapacitet. For eksempel er kapaciteten i Nairobis børne- og ungdomsdetention på 80 personer. Men da Human Rights Watch besøgte stedet i oktober 1996, boede der 153. Derudover informerede de ansatte om, at antallet af børn og unge til tider kan være så højt som 500. Årsagerne til, at børn og unge bliver sendt i detentionen, relaterer sig oftest til, at de bliver antastet $\mathrm{i}$ „vagabondering“, taget $\mathrm{i}$ at ,at tigge“ eller anses for at være ,uden for forælderlig omsorg og kontrol“. Børne- og ungdomshjemmene (som er sammenlignelige med fængsler) huser børn og unge af andre årsager end dententionen nemlig, hvis de er hjemløse, forældreløse eller forladt, eller hvis de er overført af ungdomsretten efter at have tilbragt længere perioder i detentionen, og endelig hvis de har begået mere seriøse forbrydelser. Der er 78 fængsler for voksne i Kenya. Generelt er disse fængsler overbefolkede, mangler vand og sundhedsfaciliteter, og kosten er utilstrækkelig. I løbet af de første 9 måneder af 1995 dødede 814 fanger på grund af dysenteri og diarré (Human Rights Watch 1996:74). Samtlige gadefolk, det vil sige børn, unge og ældre, er ofte og nærmest obligatoriske klienter i de ovenfor beskrevne institutioner. På gaden siger man derfor, ,at du kan ikke leve på gaden uden at have været i fængsel".

2. Se for eksempel Munyakho (1989), Project Document (1995), Stwart (1990), Undugu Society (1992-93), UNESCO Publishing (1995).

3. Se Molding (1998).

4. African Network for the Prevention and Protection Against Child Abuse and Neglect (ANPPCAN) er en veletableret kenyansk ,non-governmental organisation“ (ngo), der gennem høringer og seminarer om gadebørn i Kenya forsøger at koordinere indsatsen af ngo'er, kirkeorganisationer, repræsentanter fra FN's organisationer og den kenyanske regering. 
5. Identitet defineres her som en persons oplevelse af sin egen status, som den løbende udformer sig, det vil sige en persons oplevelse af, hvem han eller hun er (Holland \& Skinner 1993:7). Identitet er således et dynamisk begreb, der relaterer sig til folks selvopfattelse. Det er i denne forbindelse vigtigt at påpege, at folks selvopfattelser bliver dannet i en social kontekst, hvor folk både tager og tilskrives identitet.

6. Jeg anvender begrebet position, som sociologen Pierre Bourdieu definerer det. En position refererer til en persons sociale omdømme og evne til at håndtere livet inden for en specifik social sammenhæng som for eksempel den akademiske verden. Det skal i denne sammenhæng understreges, at evner ikke anskues som noget medfødt og dermed noget, der er på forhånd givet, men som værende dynamiske og relaterede til det enkelte individs relation til og interaktion inden for forskellige sociale verdener. Mere præcist definerer Bourdieu en position i relation til andre positioner inden for et socialt felt og ud fra mængden af symbolsk kapital, som det enkelte individ besidder i feltet (Bourdieu \& Wacquant 1992:16). Begreberne symbolsk kapital og felt vil blive yderligere diskuteret og defineret i afsnittet „Et felt“ .

7. I denne artikel er det overvejende gadeeksperterne og deres karakteristika frem for novicerne, som fokus er rettet mod.

8. Den proces, hvorigennem gadelivet gradvist inkorporeres i den enkelte aktør qua dennes interaktion med de andre aktører i feltet, beskriver jeg i Molding (1998).

9. Vigtigheden af at vise konformitet i forhold til nogle fælles adfærdsformer er også blevet fremhævet $i$ andre antropologiske studier af ungdoms- og gadekulturer (Sansone 1995; Vigil 1994). I et studie af unge vestinderes fortolkning af deres kreole baggrund og kultur påpeger antropologen Livio Sansone, hvordan for eksempel musiksmag og tøjstil er med til at forme en fælles subkulturel identitet (Sansone 1995:116).

10. Blandt gikuyuerne, som er den etniske gruppe, størstedelen af gadefolkene kommer fra, var voksende respekt og sociale rettigheder traditionelt forbundet med en bevægelse op ad i aldershierarkierne. Disse bevægelser blev fejret og markeret i forbindelse med begivenheder som initiationsritualer, bryllupper, fødslen af det første barn, det første barns omskæring osv (Kenyatta 1995:108). I dagens Kenya markeres begivenheder som bryllupper og omskæringer stadig i de forskellige befolkningsgrupper, for eksempel blandt masaiierne, luhyaerne og gikuyuerne.

11. Se også Molding (1998).

12. Børneprostitution er forbudt i Kenya, og det er derfor et følsomt emne blandt gadefolk og i stigende grad også i offentlige mediedebatter. Som en følge heraf er klienter involveret $\mathrm{i}$ børneprostitution ofte flove over og angste for at skulle forhandle direkte med de yngre piger. De ældre og erfarne gadepiger og kvinder fungerer blandt andet derfor gerne som mellemmænd i forhandlingerne.

\title{
Litteratur
}

\begin{abstract}
ANPPCAN
$1995 \quad$ Hearing on Street Children in Kenya. African Network for the Prevention and Protection against Child Abuse and Neglect (ANPPCAN), Nairobi 4.-5.11. 1994.
\end{abstract}

Bourdieu, P.

1990

The Logic of Practice. Stanford: Stanford University Press.

1994

Language and Symbolic Power. Cambridge: Polity Press.

Bourdieu, P. \& L. J. D. Wacquant,

1992 An Invitation to Reflexive Sociology. Cambridge: Polity Press.

D'Andrade, R. \& C. Strauss

1992 Human Motives and Cultural Models. Cambridge: Cambridge University Press.

Glauser, B.

1990 Street Children: Deconstructing a Construct. I: A. James \& A. Prout (red.): Constructing and Reconstructing Childhood: Contemporary Issues in the Sociological Study of Childhood. London: Flamer Press. 
Hervik, P.

$1994 \quad$ Voices in and about Maya Religion, the Competing Constructions of Participants and Authorities. Upubliceret artikel.

Holland, D. \& D. G. Skinner

1993 The Co-Development of Identity, Agency and Lived Worlds. I: J. Tudge, M. Shanahan \& J. Valsiner (red.): Comparative Approaches in Developmental Science.

Human Rights Watch

1997 Juvenile Injustice, Police Abuse and Detention of Street Children in Kenya. Human Rights Watch Children's Rights Project. USA.

Kenyatta, J.

$1995 \quad$ Facing Mount Kenya. Nairobi: Kenway Publications.

Molding, M.

1998

Streetwise. An Analysis of Street Life and Survival in Urban Kenya. Specialerække nr. 106, Institut for Antropologi, Københavns Universitet.

Munyakho, D

1989 Kenya: Parking Boys of Nairobi. I: H. Bhaskra, D. D’Monte, N. Huda, J. Mukela, D.

Munyakho, A. Ngaiza, W. Ogana \& U. Rai (red.): Against All Odds. Breaking the Poverty

Trap. The Panos Institute, London: Wanigasundara.

Nelson, N.

1993

Selling her Kiosk: Kikuyu Notions of Sexuality and Sex for Sale in Mathare Valley, Kenya. I: P. Caplan (red.): The Cultural Construction of Sexuality. London: Routledge

Project Document

1995 Rescue Dada Centre. Rehabilitation of Young Street Girls. Archdiocese of Nairobi.

Sansone, L.

1995

The Making of Black Youth Culture. Lower Class Young Men of Surinamese Origin in Amsterdam. I: V. Amit-Talai \& H. Wullf (red.): Youth Cultures. A Cross-Cultural Perspective. London: Routledge.

Stwart, J. 1990

Malunde, the Street Children of Hilbrow. Johannesburg: Witwatersrand University Press.

Undugu Society

1992-93 Survival. The Undugu Society of Kenya's Integrated Approach to Urban Development. Nairobi.

UNESCO

1995 Working with Street Children. Selected Case Studies from Africa, Asia and Latin America. Paris: UNESCO Publishing.

Vigil, J. D. 1994

Barrio Gangs, Street Life and Identity in Southern California.

Austin: University of Texas Press. 
